\title{
Epigenetic inactivation of TCF2 in ovarian cancer and various cancer cell lines
}

\author{
K Terasawa ${ }^{1,7}$, M Toyota ${ }^{*, 2,3,4,7}$, S Sagae', K Ogi ${ }^{2}$, H Suzuki ${ }^{5}$, T Sonoda $^{5}, K_{\text {Akino }}{ }^{2,3}$, R Maruyama $^{3}$, \\ N Nishikawa ${ }^{2,6}, \mathrm{~K} \mathrm{Imai}^{3}$, Y Shinomura ${ }^{3}$, T Saito' and T Tokino ${ }^{2}$ \\ 'Department of Obstetrics and Gynecology, Sapporo Medical University, Sapporo 060-8543, Japan; ²Department of Molecular Biology, Cancer Research \\ Institute, Sapporo Medical University, Sapporo 060-8543, Japan; ${ }^{3}$ First Department of Internal Medicine, Sapporo Medical University, Sapporo 060- \\ 8543, Japan; ${ }^{4}$ PRESTO, JST, Kawaguchi, Japan; ${ }^{5}$ Department of Public Health, Sapporo 060-8543, Japan; ${ }^{6}$ First Department of Surgery, Sapporo Medical \\ University, Sapporo 060-8543, Japan
}

Transcription factor 2 gene (TCF2) encodes hepatocyte nuclear factor $\mid \beta(H N F \mid \beta)$, a transcription factor associated with development and metabolism. Mutation of TCF2 has been observed in renal cell cancer, and by screening aberrantly methylated genes, we have now identified TCF2 as a target for epigenetic inactivation in ovarian cancer. TCF2 was methylated in 53\% of ovarian cancer cell lines and $26 \%$ of primary ovarian cancers, resulting in loss of the gene's expression. TCF2 expression was restored by treating cells with a methyltransferase inhibitor, 5 -aza-2'deoxycitidine (5-aza-dC). In addition, chromatin immunoprecipitation showed deacetylation of histone $\mathrm{H} 3$ in methylated cells and, when combined with 5-aza-dC, the histone deacetylase inhibitor trichostatin $\mathrm{A}$ synergistically induced TCF2 expression. Epigenetic inactivation of TCF2 was also seen in colorectal, gastric and pancreatic cell lines, suggesting general involvement of epigenetic inactivation of TCF2 in tumorigenesis. Restoration of TCF2 expression induced expression of HNF4 $\alpha$, a transcriptional target of HNFI $\beta$, indicating that epigenetic silencing of TCF2 leads to alteration of the hepatocyte nuclear factor network in tumours. These results suggest that TCF2 is involved in the development of ovarian cancers and may represent a useful target for their detection and treatment.

British Journal of Cancer (2006) 94, 914-921. doi: I 0.1038/sj.bjc.6602984 www.bjcancer.com

Published online 14 February 2006

(c) 2006 Cancer Research UK

Keywords: epigenetics; methylation; ovarian cancer

Ovarian cancer is the most deadly of gynecological malignancies, with an overall 5 -year survival rate of $<30 \%$. In large part, this is because the disease usually presents at an advanced stage, as there are no overt symptoms at early stages. Ovarian cancers are morphologically and biologically heterogeneous and associated with distinct genetic alterations. For example, the serous type frequently shows p53 mutations, the mucinous type K-ras mutations, and the endometrioid type $\beta$-catenin mutations. The molecular pathogenesis of ovarian cancer is not fully understood, however, and it is hoped that a better understanding of the molecular mechanisms underlying the tumorigenic process will lead to earlier diagnosis, novel therapies and, ultimately, better outcomes.

DNA methylation can be a good molecular marker by which to identify genes inactivated in cancer (Jones \& Baylin, 2002; Laird, 2003; Issa, 2004; Costello, 2005), and several techniques, including restriction landmark genome scanning and methylation-sensitive arbitrary primer PCR, have been used to screen for aberrantly methylated DNA fragments in tumour cells (Zardo et al, 2002; Yu

*Correspondence: Dr M Toyota, Department of Molecular Biology, Cancer Research Institute, South-I West-17, Chuo-ku, Sapporo, Hokkaido, Japan; E-mail: mtoyota@sapmed.ac.jp

7 These authors contributed equally to this work

Received 18 July 2005; revised 22 November 2005; accepted 16 January 2006; published online 14 February 2006 et al, 2005). In addition, we have developed a novel methylation screening technique, methylated $\mathrm{CpG}$ island amplification (MCA), which we have used to identify DNA fragments that are hypermethylated in cancer (Toyota et al, 1999). And by coupling MCA to representational difference analysis (RDA) we have been able to identify those genes inactivated by hypermethylation (Toyota et al, 1999; Ueki et al, 2001; Obata et al, 2003; Palmisano et al, 2003; Yamada et al, 2004). When we used MCA in combination with RDA to screen for genes methylated in an ovarian cancer cell line, we observed for the first time that transcription factor 2 gene (TCF2) is a target for epigenetic inactivation.

TCF1 and TCF2, respectively, encode the transcription factors hepatocyte nuclear factor $1 \alpha$ and $\beta$ (HNF1 $\alpha$ and HNF1 $\beta$ ), two POU-homeodomain proteins that bind to an essential element in the proximal promoter sequences of albumin and many other tissue-specific genes and are associated with development, metabolism and cancer (Cereghini et al, 1987; Courtois et al, 1987; Frain et al, 1989; Rey-Campos et al, 1991). For instance, TCF2 defects cause developmental abnormalities in multiple tissues, including kidney and pancreas (Horikawa et al, 1997; Haumaitre et al, 2005), and Bluteau et al (2002) identified biallelic mutations of TCF1 in hepatic adenomas (Bluteau et al, 2002). Subsequently, mutations of TCF1 also were found in colorectal cancer with MSI (Laurent-Puig et al, 2003) and endometrial tumours (Rebouissou et al, 2004), while Rebouissou et al (2005) also identified mutations of TCF2 in renal carcinomas. 
With that as background, our aim in the present study was to evaluate TCF2 methylation in panels of ovarian cancer cell lines and primary ovarian cancers. Our findings indicate that TCF2 expression is lost in ovarian cancer cell lines that show methylation and that expression is restored by treating cells with a methyltransferase inhibitor, confirming epigenetic silencing of the gene. Moreover, restoration of TCF2 expression induced expression of $H N F 4 \alpha$, a transcriptional target of $H N F 1 \beta$, indicating that epigenetic silencing of TCF2 leads to alteration of the hepatocyte nuclear factor network in tumours. These results suggest that epigenetic inactivation of TCF2 is involved in development of ovarian cancer.

\section{MATERIALS AND METHODS}

\section{Cell lines and specimens}

Eight ovarian cancer cell lines (SKOV-3, OVCAR-3, PA-1, Caov-3, TOV112D, TOV21G, SW626, OV-90), eight colorectal cancer cell lines (RKO, HCT116, DLD-1, LoVo, HT29, Colo320, SW480, Colo205), and eight gastric cancer cell lines (MKN7, MKN45, MKN74, JRST, KatoIII, AZ521, NUGC3, NUGC4), were obtained from the American Tissue Culture Collection (Manassas, VA, USA) or the JCRB (Tokyo, Japan). Seven pancreatic cancer cell lines (MIAPACA2, PK-3, PK1NC, PK-8, CF-PAC, PK-9, PK-45) were obtained from American Tissue Culture Collection or from Cell Resource Center for Biomedical Research, Institute of Development, Aging and Cancer, Tohoku University (Sendai, Japan). Seven other ovarian cancer cell lines (MH, KURA, AMOC-2, MCAS, KF, $\mathrm{KFr}, \mathrm{HTBOA}$ ) were described previously (Ishiwata et al, 1986; Kikuchi et al, 1986), as was the cervical cancer cell line (OMC-1) used (Ueda et al, 1989). All cell lines were cultured in RPMI 1640 (Life Technologies Inc., Rockville, MD, USA) supplemented with $10 \%$ fetal bovine serum and incubated under a $5 \% \quad \mathrm{CO}_{2}$ atmosphere at $37^{\circ} \mathrm{C}$. Two cell lines that showed aberrant methylation and diminished gene expression were treated with the indicated concentration of the methyltransferase inhibitor 5-aza-2'deoxycitidine (5-aza-dC) for $96 \mathrm{~h}$ and/or the histone deacetylase inhibitor trichostatin A (TSA) for $24 \mathrm{~h}$. The cells were then harvested and the total RNA extracted using Isogen (Nippongene, Tokyo, Japan). In addition, four samples of normal ovarian tissue and 98 ovarian cancer specimens were obtaining from Sapporo Medical University Hospital at surgery and stored at $-80^{\circ} \mathrm{C}$. In accordance with institutional guidelines (Ishioka et al, 2003), all patients gave informed consent prior to collection of the specimens.

\section{MCA/RDA}

MCA was carried out as described previously (Toyota et al, 1999). We used the MCA amplicon from the OVCAR-3 ovarian cancer cell line as a tester and that from normal ovarian tissue as a driver. After two rounds of subtraction by RDA, the PCR products were digested with $\mathrm{XmaI}$ and ligated to pBluescriptII (Stratagene). The inserts were then sequenced using an ABI3100 Genetic Analyzer (Applied Biosystems, Foster City, CA, USA). Database analysis was performed using Blast and BLAT.

\section{Bisulphite treatment of genomic DNA}

Genomic DNA was isolated from cell lines and primary tissue samples (cancerous and normal) using the phenol-chloroform method and then treated with sodium bisulphite as described previously (Clark et al, 1994). Briefly, $2 \mu \mathrm{g}$ of DNA were denatured for $10 \mathrm{~min}$ at $37^{\circ} \mathrm{C}$ in $2 \mathrm{M} \mathrm{NaOH}$, after which $30 \mu \mathrm{l}$ of $10 \mathrm{~mm}$ hydroquinone (Sigma Chemical Co, St Louis, MO, USA) and $520 \mu \mathrm{l}$ of $3 \mathrm{M}$ sodium bisulphite were added. The mixture was then incubated for $16 \mathrm{~h}$ at $50^{\circ} \mathrm{C}$, and the modified DNA was purified using a Wizard DNA Purification System (Promega, Madison, WI, USA). After treating the DNA with $\mathrm{NaOH}$ a second time, the resultant DNA precipitate was resuspended in $20 \mu \mathrm{l}$ of TE buffer and stored at $-80^{\circ} \mathrm{C}$ until use.

\section{Combined bisulphite restriction analysis}

The methylation status of TCF2 was examined using combined bisulphite restriction analysis (COBRA), a semiquantitative bisulphite-PCR analysis (Xiong \& Laird, 1997). Primers were designed so that both methylated and unmethylated DNA would be amplified equally. PCR was carried out in a 50- $\mu$ l volume containing $1 \times$ PCR buffer $(67 \mathrm{~mm}$ Tris- $\mathrm{HCl}(\mathrm{pH} 8.8), 16.6 \mathrm{~mm}$ $\left(\mathrm{NH}_{4}\right)_{2} \mathrm{SO}_{4}, 6.7 \mathrm{mM} \quad \mathrm{MgCl}_{2}$, and $10 \mathrm{~mm} \quad \beta$-mercaptoethanol), $0.25 \mathrm{~mm}$ dNTP mixture, $0.5 \mu \mathrm{m}$ each primer and $1.0 \mathrm{U}$ of Hot Start Ex-Taq polymerase (TaKaRa). The oligonucleotide sequences used for bisulphite-PCR were $5^{\prime}$-GGGGTYGAGTTYGATATTAAGT-3' (TCF2COBRA-F) and 5'-TACCTAAACATCCRATCCACCT- $3^{\prime}$ (TCF2COBRA-R). The PCR products were digested with the restriction enzyme TaiI (Fermentas Life Sciences, Ontario, Canada), which cleaves CpG sites retained because of methylation. After ethanol precipitation, the DNA was subjected to $2.5 \%$ agarose gel electrophoresis and stained with ethidium bromide.

\section{Direct-sequencing of Bisulphite-PCR products}

The PCR products obtained with COBRA were used for directsequencing. Briefly, $10 \mu \mathrm{l}$ of bisulphite-PCR product were electrophoresed in $1 \%$ SeaPlaque agarose gel, excised, purified using a PCR Purification System (Promega, Madison, WI, USA) and eluted in $50 \mu \mathrm{l}$ of water. Samples $(5 \mu \mathrm{l})$ were then used as templates for the sequencing reaction, which was carried out using a BigDye terminator cycle sequencing kit (Applied Biosystems, Foster City, CA, USA) with an ABI PRISM 3100 sequencer according to the manufacturer's guidelines (Applied Biosystems).

\section{Reverse transcription-polymerase chain reaction}

Expression of TCF2 and HNF4 $\alpha$ was analyzed using reverse transcription - polymerase chain reaction (RT-PCR). Total RNA was extracted from cell lines using Trizol (Life Technologies Inc., Gaithersburg, MD, USA) according to the manufacturer's instructions. The RT reaction was carried out with $2 \mu \mathrm{g}$ of total RNA using a SuperScript II First-Strand Synthesis System (Invitrogen Inc., Grand Island, NY, USA) with random primer. PCR was carried out in solution containing $1 \times$ PCR buffer (TaKaRa), $200 \mu \mathrm{M}$ each deoxynucleotide triphosphate, $2.5 \mathrm{pmol}$ of each primer, $1 \mathrm{U}$ of ExTaq polymerase (TaKaRa) and $5 \%(\mathrm{v} / \mathrm{v})$ DMSO. The oligonucleotide primer sequences used were $5^{\prime}$-CTATGACACACCTCC CATCCTCAAG-3' (TCF2RT-F), 5'-GTCTGGTTGAATTGTCGGAG GATCT-3' (TCF2RT-R), 5'-CGGCAGTGCGTGGTGGACAAAGAC-3' (HNF4- $\alpha$ RT-F), and $5^{\prime}$-CACACACATCTGCGATGCTGGCAAT- $3^{\prime}$ (HNF-4 $\alpha$ RT-R). The PCR cycling protocol consisted of 1 cycle at $95^{\circ} \mathrm{C}$ for $5 \mathrm{~min}$ and 32 cycles at $95^{\circ} \mathrm{C}$ for $30 \mathrm{~s}, 60^{\circ} \mathrm{C}$ for $30 \mathrm{~s}$ and $72^{\circ} \mathrm{C}$ for $45 \mathrm{~s}$. The housekeeping gene GAPDH served as an internal control to confirm the success of the RT reaction. The PCR products were subjected to $2.5 \%$ agarose gel electrophoresis.

For quantitative analysis, real-time PCR was carried out using a TaqMan PCR system (Applied Biosystems). PCR was carried out in $50 \mu \mathrm{l}$ of solution containing $1 \mu \mathrm{l}$ of cDNA, $2.5 \mathrm{pmol}$ of each primer and $25 \mu$ l of TaqMan PCR mixture (Applied Biosystems). The PCR cycling protocol consisted of 1 cycle at $95^{\circ} \mathrm{C}$ for $5 \mathrm{~min}$ and 40 cycles at $95^{\circ} \mathrm{C}$ for $30 \mathrm{~s}$ and $60^{\circ} \mathrm{C}$ for $1 \mathrm{~min}$. Fluorescent signals were detected using an ABI 7000 Prism 7000 (Applied Biosystems), and the accumulation of $P C R$ product was measured in real time as the increase in the fluorescent signal. Data were analysed using ABI Prism 7000 SDS Software (Applied Biosystems). The probes and 
primer sets were ABI Assay on Demand and Ref Hs00172123 for TCF2 and Hs00230853 for HNF4 $\alpha$ (Applied Biosystems).

\section{Mutational analysis}

In all, 10 pairs of primers for individually amplifying and screening exons 1-9 of TCF2 were used for amplifying genomic DNA. Spanning the entire coding region of the gene, these primers were specified by a Human BLAT Search (Chr17q12, position: $33,120,547-33,179,182)$, and their sequences are available upon request. PCR was carried out in a $50-\mu \mathrm{l}$ reaction mixture containing $1 \times$ PCR buffer (TaKaRa), $1 \mu \mathrm{M}$ primers, $0.25 \mathrm{~mm}$ dNTP mixture and $1.0 \mathrm{U}$ of Hot Start Taq polymerase (TaKaRa). The amplified PCR products were electrophoresed in 1\% Seaplaque gels, excised, purified using a Gel purification system (Qiagen, Hilden, Germany) and sequenced. The primer sequences and PCR conditions used for mutational analysis are available upon request.

\section{Chromatin immunoprecipitation and PCR}

Chromatin immunoprecipitation was carried out as described previously (Ueno et al, 2004). Briefly, cells were incubated in $1 \%$ formaldehyde for $10 \mathrm{~min}$ at $37^{\circ} \mathrm{C}$. The nuclei were then collected, sonicated to yield fragments ranging in size from 300 to $2000 \mathrm{bp}$, and immunoprecipitated with anti-histone $\mathrm{H} 3$ antibody (Upstate Biotechnology, Lake Placid, NY, USA), which specifically recognizes the diacetylated lysine residues (lysines 9 and 14) of histone H3. The chromatin was recovered using protein A Sepharose. Realtime PCR was then performed using $1 \mu \mathrm{l}$ of chromatin DNA as shown above. The primer sequences used were $5^{\prime}$-TGGATTT GGGGTTTGCTTGTGA-3' (TCF2ChIP-F) and $5^{\prime}$-GACGTGAGCTT GGACACCATTTTC-3' (TCF2ChIP-R). Standard curves relating initial template copy number to fluorescence and amplification cycle were generated using the amplified PCR product as a template, and were used to calculate the DNA copy number in each sample. Ratios of the intensities of the TCF2 and GAPDH signals were used as a relative measure of the level of TCF2 expression in each specimen.

\section{Statistical analysis}

The statistical analysis was carried out using StatView software (SAS Institute Inc., Cary, NC, USA). Fisher's exact test (two-sided) was used to determine the association between TCF2 methylation and clinicopathological features. Values of $P<0.05$ were considered significant. Overall survival time was defined as the period between the diagnosis of ovarian cancer and the time of death. Differences between survival curves were assessed by KaplanMeier analysis using the log-rank test.

\section{RESULTS}

\section{Identification of TCF2 as a target for epigenetic inactivation in ovarian cancer}

Using MCA coupled with RDA, we recovered DNA fragments located within intron 1 of TCF2 (Figure $1 \mathrm{~A}$ ). The $5^{\prime}$ region of TCF2 contains a $\mathrm{CpG}$ rich region that fulfills the criteria for a $\mathrm{CpG}$ island (observed CpG: expected $\mathrm{CpG}=0.821$, GC content $58.9 \%$, length $3.4 \mathrm{~kb}$ ). Then when we used COBRA to examine the methylation status of this region in 15 ovarian and one cervical cancer cell line (Figure 1B), we found it to be densely methylated in eight $(53 \%)$ of the ovarian cancer cell lines, but not in the cervical cancer cell line. Moreover, using the same methodology, we determined that TCF2 was aberrantly methylated in 26 of $98(26.5 \%)$ primary ovarian cancers, but not in any of the four samples of normal ovarian tissue analysed (Figure 1C). Apparently, methylation of TCF2 is a cancer-specific event and is not a cell line-specific one.
A

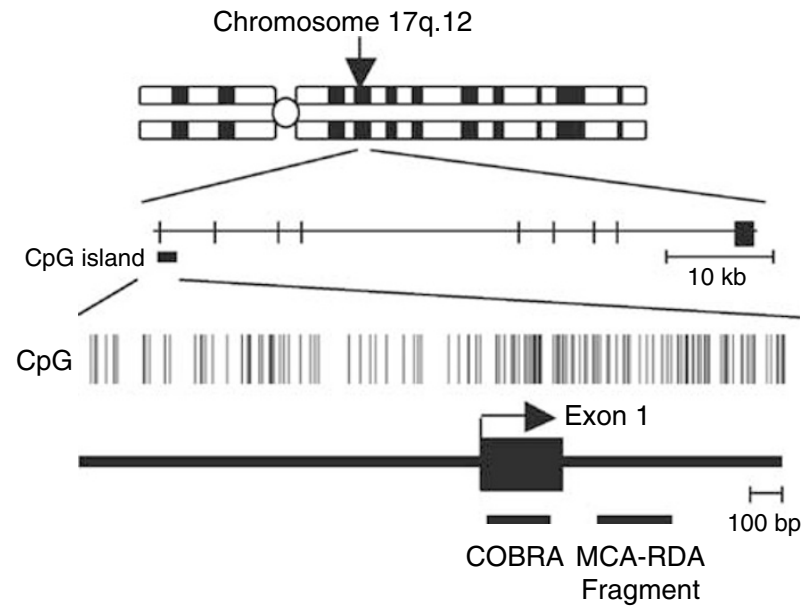

B
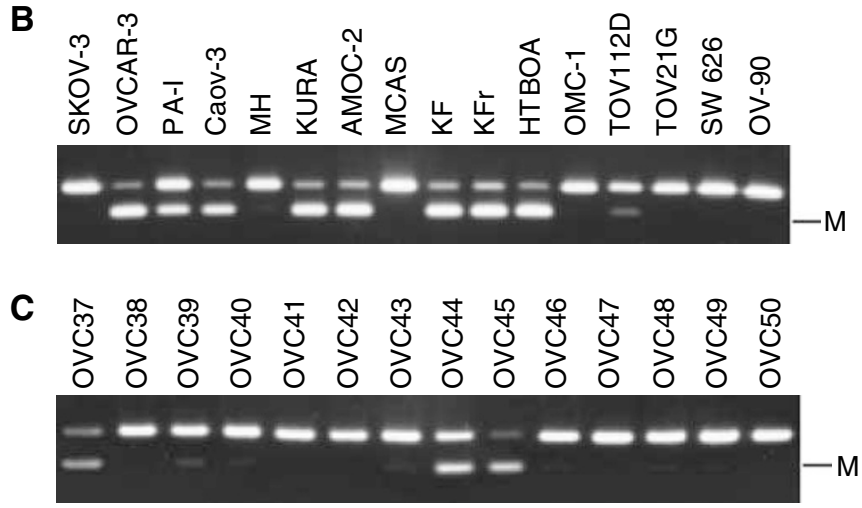

Figure I Identification of TCF2 as a target for methylation in ovarian cancers. (A) Schematic diagram of the CPG island of TCF2. The chromosomal region in which TCF2 is situated is shown at the top. Vertical bars indicate CPG sites. Exon is shown by a solid box with an arrow indicating the transcription start site. The region analysed using COBRA and the position of the clone obtained with MCA are shown by respective horizontal bars. (B) Analysis of TCF2 methylation in ovarian cancer cell lines using COBRA. PCR products contain a restriction site for Tail, which recognizes ACGT. The PCR products are digested only when the $\mathrm{CpG}$ sites were retained after bisulphite treatment because of methylation. The cell lines tested are shown on the top. M: methylated alleles. (C) Analysis of TCF2 methylation in primary ovarian cancer. The numbers of the cases are shown above.

To confirm whether the methylation detected by COBRA reflects the overall level of methylation in the $5^{\prime}$ region of $T C F 2$, we carried out bisulphite-sequencing of the gene (Figure 2A and B). Again, methylation of TCF2 was not detected in normal ovarian tissues. On the other hand, the ovarian cancer cell lines shown by COBRA to be methylated also showed dense methylation over all their CpG islands, while those shown by COBRA not to be methylated showed no methylation of their CpG islands (Figure 2A and B). To determine whether methylation of TCF2 is correlated with gene silencing, we used RT - PCR to evaluate the gene's expression in 15 ovarian and one cervical cancer cell lines (Figure 3). No expression of TCF2 was detected in any of the nine cell lines that showed methylation; that is, methylation was significantly associated with an absence of TCF 2 mRNA $(P<0.001$, Fisher's exact test, twosided). By contrast, all seven cell lines that showed no methylation expressed the transcript, indicating a role for DNA methylation in the silencing of TCF2.

To determine whether TCF2 is inactivated by mutation, we first carried out direct sequence analysis of TCF2 using DNA from 
A
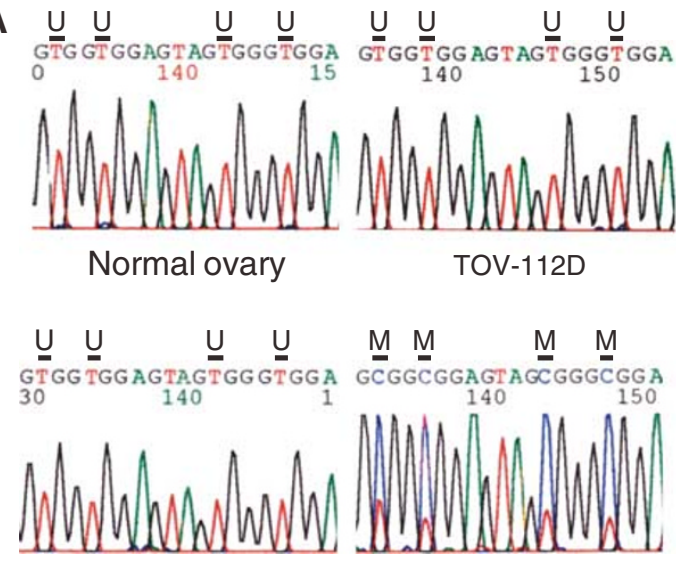

MCAS

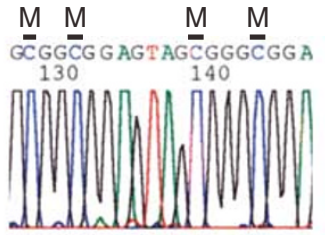

AMOC2

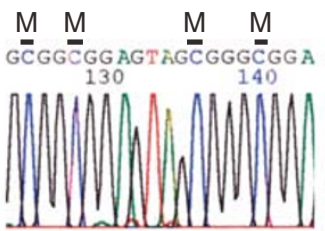

Caov-3

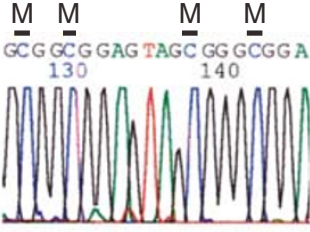

$\mathrm{KFr}$

B

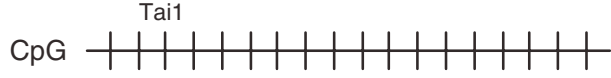

Normal ovary 000000000000000000

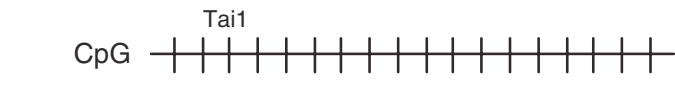

TOV-112D 000000000000000000
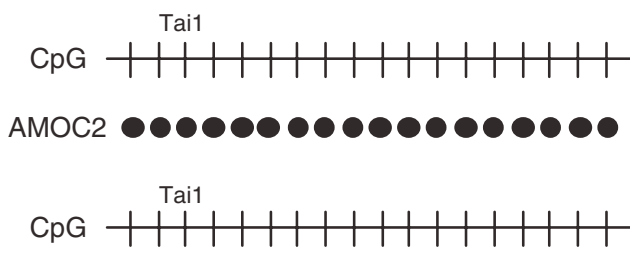

$\mathrm{KFr}$

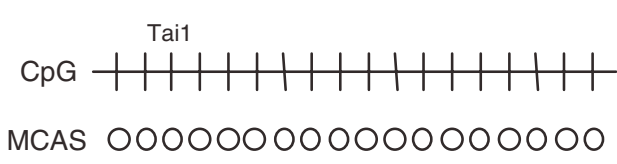

Tai1

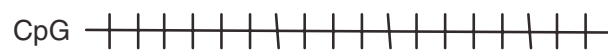

PAI-I 000000000000000000

Tai1

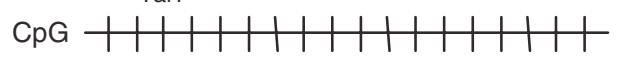

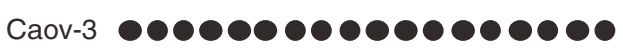

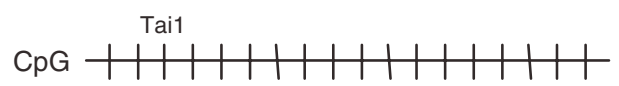

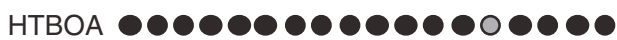

Figure 2 Bisulphite-sequencing analysis of TCF2 in ovarian cancer cell lines. (A) PCR products used for COBRA analysis were electrophoresed in agarose, excised, purified and directly sequenced. In normal ovary and TOVI I2D and MCAS cells, all of the cytosines within the CpG sites were substituted with thymines. In AMOC2, KFr, Caov-3 and HTBOA cells, all cytosines in the CpG sites remained cytosines. In PAI-I cells, the CpG sites contained a mixture of cytosines and thymines, as methylation was partial. U: unmethylated CpG sites; M: methylated CpG sites. (B) Summary of bisulphite-sequencing. Unmethylated CpG sites are indicated by open circles, and methylated CpG sites are indicated by filled circles. CpG sites that show a mixed pattern of methylated and unmethylated alleles are shown in the grey circles. Cell lines are indicated on the left. The CpG sites in the region analysed are indicated by vertical bars (top). The CPG site examined by COBRA analysis is indicated as Tail.

ovarian cancers. Using 10 sets of primers that respectively amplified exons $1-9$, we examined 15 cell lines and 33 primary ovarian tumours, and discovered two base substitutions in the introns, which were determined to be polymorphisms (data not shown, and Supplementary Figure 1). Thus, inactivation of TCF2 appears to be caused by epigenetic changes rather than genetic ones.

\section{Silencing of TCF2 in human tumour cell lines}

We next carried out COBRA using DNA from a panel of human cancer cell lines to determine the frequency with which TCF2 was methylated in other tumour types (Figure 4A). Methylation of TCF2 was detected in six of eight (75\%) colorectal, four of eight (50\%) gastric and six of seven (85.7\%) pancreatic cancer cell lines (Figure 4B). Moreover, as in ovarian cancer, expression of TCF2 was absent in cell lines that showed methylation. One colorectal cancer cell line, DLD-1, also did not express TCF2, although this cell line did not show methylation.
The role of DNA methylation and histone deacetylation in the silencing of TCF2

The role of DNA methylation in the silencing of TCF2 was further confirmed by our finding that treating cells with the methyltransferase inhibitor 5-aza-dC $(1 \mu \mathrm{M})$ restored gene expression. Of four methylated cell lines tested, all showed restored TCF2 expression following treatment with 5-aza-dC (Figure 5A). By contrast, expression of TCF2 was not restored by the histone deacetylase inhibitor TSA, but when combined with a low dose of 5-aza-dC, TSA exerted a synergistic effect augmenting gene expression (Figure 5B). Using ChIP assays to examine the acetylation status of histone $\mathrm{H} 3$, we found that DNA methylation was associated with a low level of histone acetylation, indicating that histone deacetylation, too, plays a role in the silencing of TCF2 (Figure 5C).

The role of TCF2 methylation in the regulation of HNF4 $\alpha$ We next evaluated the expression of $H N F 4 \alpha$, one of the transcriptional targets of HNF1 $\beta$, in cell lines with and without 

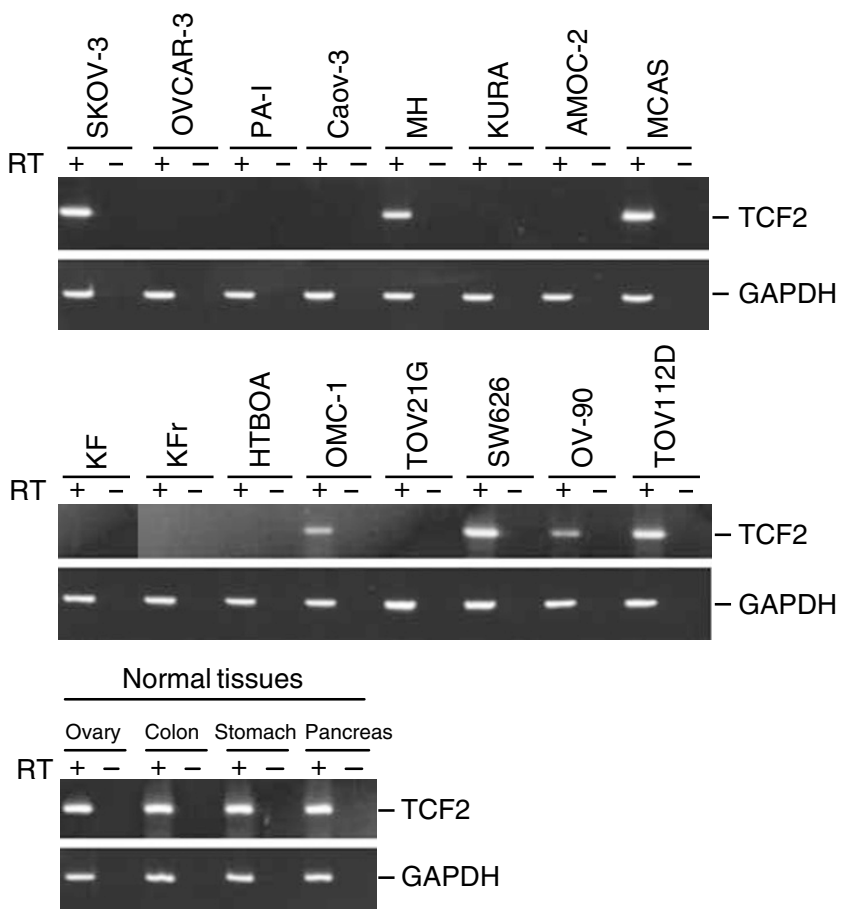

Figure 3 RT-PCR analysis of TCF2 mRNA expression in ovarian cancer cell lines. Controls consist of carrying out PCR reactions without reverse transcription (-). The cell lines examined are shown above the gels Expression of GAPDH was evaluated to confirm the integrity of cDNA.

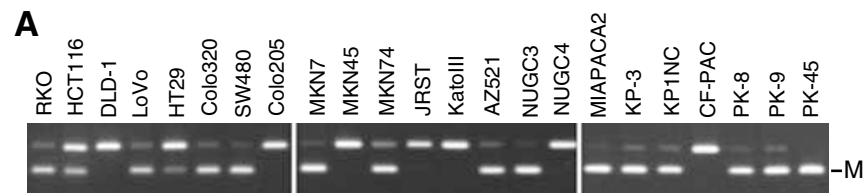

B Colo320 RKO HCT116 DLD-1 LoVo HT29 SW480 Colo205
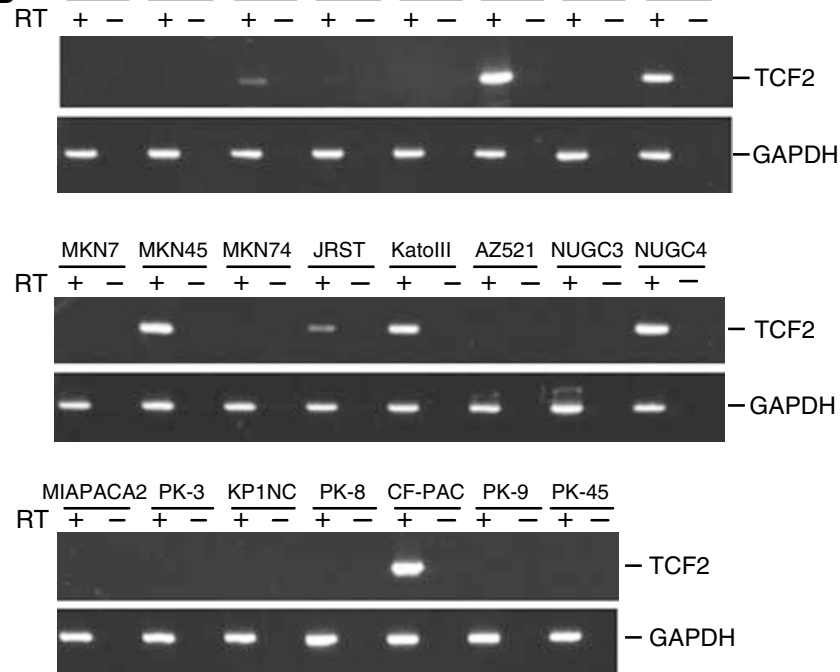

Figure 4 Epigenetic silencing of TCF2 mRNA expression in human tumour cell lines. (A) Analysis of TCF2 methylation using COBRA in colorectal, gastric and pancreatic cancer cell lines. Cell lines are shown on the top. (B) RT-PCR analysis of TCF2 mRNA expression.

TCF2 methylation (Figure 6A). Expression of HNF4 $\alpha$ was detected in all cancer cell lines that expressed TCF2. By contrast, cell lines that showed TCF2 methylation showed little or no $H N F 4 \alpha$
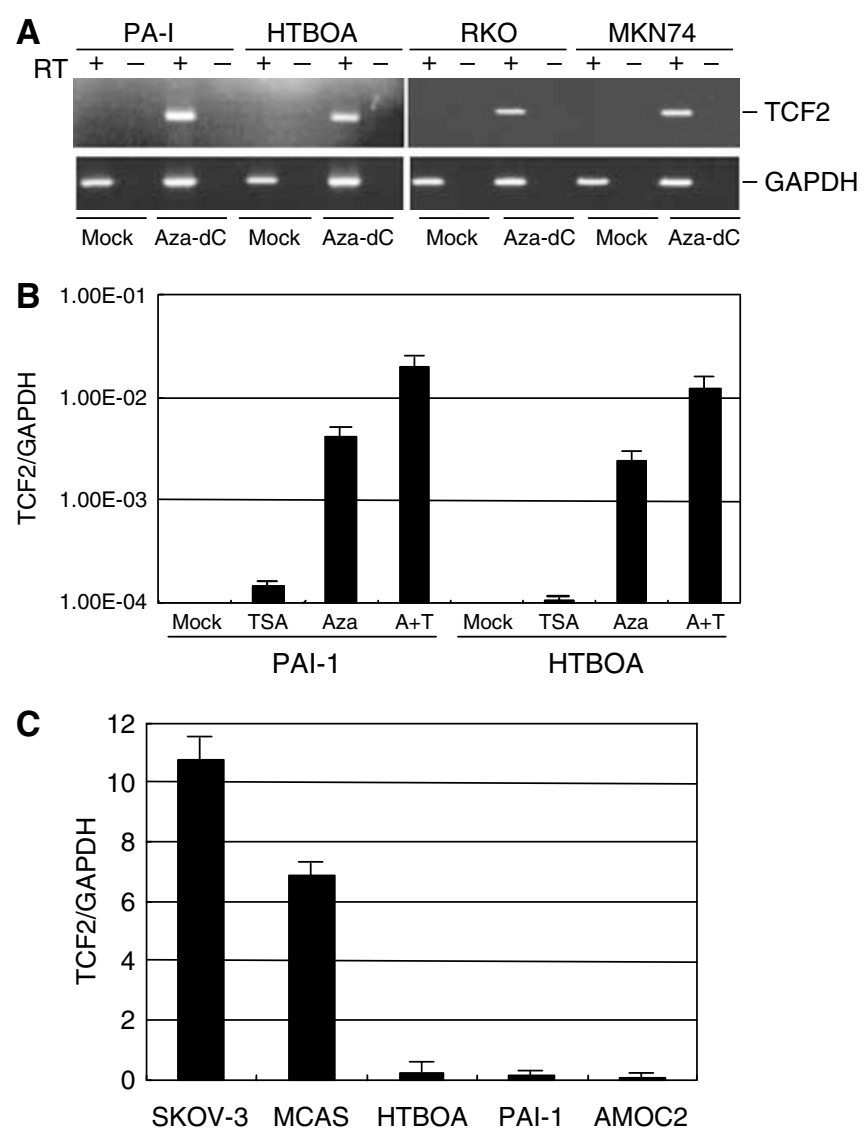

Figure 5 Silencing of TCF2 is associated with DNA methylation and histone deacetylation. (A) Restoration of TCF2 mRNA expression by 5 aza-dC. RT-PCR showed reactivation of TCF2 mRNA expression in two ovarian and two gastrointestinal cancer cell lines following treatment with $2 \mu \mathrm{M}$ of 5 -aza-dC for $72 \mathrm{~h}$. (B) Synergistic effect of 5-aza-dC and TSA. PAI-I and HTBOA ovarian cancer cells were treated with 5-aza-dC and/or TSA after which TaqMan PCR was carried out. (C) Acetylation status of histone $\mathrm{H} 3$ in cell lines with and without TCF2 methylation. Acetylation of histone $\mathrm{H} 3$ was assessed using ChIP assays followed by real-time PCR. In both (B, C) levels of TCF2 mRNA are normalised to those of GAPDH mRNA.

expression. Notably, treating cells with 5-aza-dC upregulated expression of HNF4 $\alpha$ (Figure $6 \mathrm{~B}$ and $\mathrm{C}$ ). As the $5^{\prime}$ region of $H N F 4 \alpha$ does not contain a CpG island, the effect of 5-aza-dC on the gene's expression is likely not associated with demethylation of its promoter, but instead underscores the importance of TCF2 expression, and thus $\mathrm{HNF} 1 \beta$, in the regulation of HNF $4 \alpha$.

\section{Clinicopathological features of primary ovarian cancer with or without TCF2 methylation}

Finally, we examined the clinicopathological features of ovarian cancers with and without TCF2 methylation (Table 1). Aberrant methylation of TCF2 was detected in 12 of 29 (41.3\%) serous tumours, three of $12(25.0 \%)$ mucinous tumours, eight of 28 $(28.6 \%)$ endometrioid tumours and three of $12(25.0 \%)$ others (undifferentiated, mixed type), but in none of the $17(0 \%)$ clear cell tumours. Methylation of TCF2 was detected significantly less frequently in the clear cell phenotype than the other types ( $0 \%$ vs $32.1 \%$, Fisher's Exact test, $P=0.005$ ), but there was no significant association with any other clinicopathological feature (patients' age, FIGO clinical stage, and pathological grade). There was also no correlation between the patients' prognoses and the TCF2 methylation status (data not shown, and Supplementary Figure 2). 
A

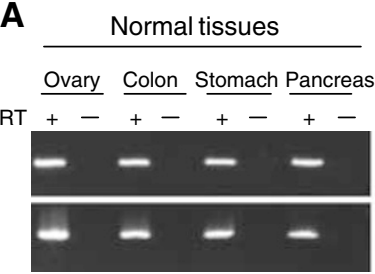

TCF2-unmethylated

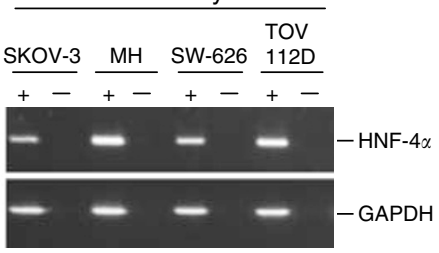

TCF2-methylated
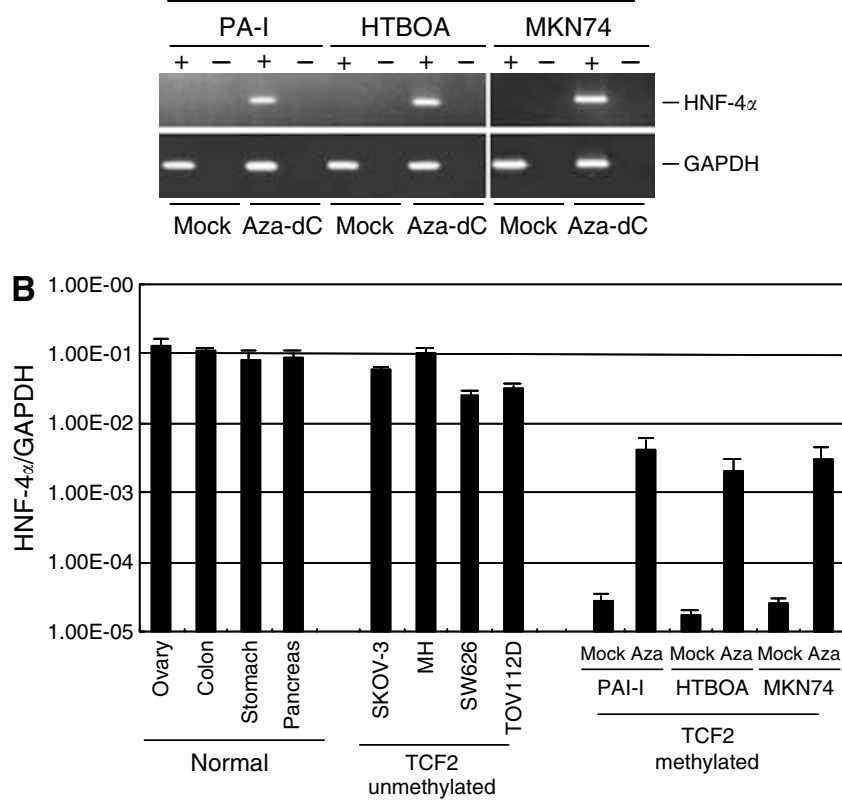

Figure 6 Analysis of HNF4 $\alpha$ mRNA expression. (A) Expression of HNF- $4 \alpha$ in cancer cell lines and normal tissues was analysed by RT-PCR. Cell lines, TCF2 methylation statuses, and tissue types are shown on the top. PAI-I, HTBOA and MKN74 cells were treated with 5-aza-dC (Aza$\mathrm{dC}$ ) and examined for restoration of HNF-4 $\alpha$. (B) Quantitative analysis of HNF- $4 \alpha$ mRNA expression using real-time PCR. Levels of HNF- $4 \alpha$ mRNA were normalised to those of GAPDH mRNA.

\section{DISCUSSION}

The transduction network associated with tumorigenesis and the progression of ovarian cancer is not fully understood, although numerous studies indicate that DNA methylation plays a key role in human neoplasia (Jones \& Baylin, 2002; Laird, 2003; Issa, 2004; Costello, 2005). Although methylation of several cancer-related genes has been reported in ovarian cancer ( $\mathrm{Yu}$ et al, 1999; Terasawa et al, 2004), the methylated genes have not yet been fully characterised. Using the MCA genome screening technique coupled with RDA, we identified TCF2 as a novel target of epigenetic inactivation through methylation in ovarian cancer. The Methylation of TCF2 was cancer-specific and, together with histone deacetylation, may be involved in tumorigenesis in a subset of ovarian cancers. It has been reported that patients with germ line mutation of TCF2 develop renal tumours (BellanneChantelot et al, 2004), and TCF2 mutations have been identified in renal cell cancer (Rebouissou et al, 2005). On the other hand, no TCF2 mutation has been previously observed in ovarian cancer (Rebouissou et al, 2005), which is consistent with our present finding that TCF2 is not mutated in ovarian cancer. Apparently, TCF2 expression is silenced by an epigenetic rather than genetic mechanism. That methylation of TCF2 was also detected in colorectal, gastric and pancreatic cancer cell lines suggests TCF2 is prone to methylation in many types of cancer and may thus play a
Table I Clinicopathological features of ovarian cancer with and without methylation of TCF2

\begin{tabular}{lcr}
\hline & Methylated (\%) & Unmethylated (\%) \\
\hline Stage $^{\mathrm{a}}$ & & \\
I & $8(25.8)$ & $23(74.2)$ \\
II & $1(33.3)$ & $2(66.7)$ \\
III & $15(26.3)$ & $42(73.7)$ \\
IV & $2(25)$ & $5(75)$ \\
& & \\
Histology & $12(41.4)$ & $17(58.6)$ \\
Serous & $3(25.0)$ & $9(75.0)$ \\
Mucinous & $8(28.6)$ & $20(71.4)$ \\
Endometrioid & $0(0)$ & $17(100)$ \\
Clear cell & $3(25.0)$ & $9(75.0)$ \\
Others & & \\
\hline
\end{tabular}

aMethylation of TCF2 was not associated with the stage of the tumours. ${ }^{b}$ Methylation of TCF2 was less frequently observed in clear cell types than other types $(P=0.005$, Fisher's exact test, two-sided).

general role in tumorigenesis. In addition, one ovarian cancer cell line, TOV112D, and one colorectal cancer cell line, DLD-1, did not express TCF2, although little or no methylation was detected in tumours. Genes silenced in cancer are often not expressed in cancer cell lines (Suzuki et al, 2002), and their silencing may be caused by mechanisms other than methylation, for example by the absence of a transcription factor or histone modification (Kondo et al, 2004).

The methylation profile of ovarian cancer may be a useful diagnostic marker with which to predict recurrence, resistance to chemotherapy and survival (Balch et al, 2004). We and others have reported that TMS1, 14-3-3sigma and WT1 genes are methylated more frequently in clear cell tumours than in other tumour types (Kaneuchi et al, 2004; Terasawa et al, 2004; Kaneuchi et al, 2005), whereas methylation of SFRP1, 18S and 28S ribosomal DNA genes is more frequently detected in nonclear cell tumours, such as the serous type (Takada et al, 2004; Chan et al, 2005). Although the molecular mechanisms responsible for the differing methylation profiles in different tumour types remains unclear, gene methylation may have relevance in the clinical situation. For instance, clear cell ovarian cancers are reportedly more resistant to chemotherapy than other types (Sugiyama et al, 2000), and this difference in sensitivity may be caused in part by differences in the genes methylated in clear cell and nonclear cell tumours. In fact, Teodoridis et al (2005) reported that methylation of genes involved in DNA repair was significantly associated with response to chemotherapy, while Chan et al (2005) reported that methylation of $18 \mathrm{~S}$ and $28 \mathrm{~S}$ ribosomal DNA genes is associated with longer progression-free survival in ovarian cancer. Taken together, these results suggest that differences in the epigenetic signatures between clear cell and other types of ovarian cancer may be a useful diagnostic indicator.

The specific role of TCF2 methylation in the development and progression of ovarian cancer remains unknown, but TCF2 mutations are known to affect expression of downstream genes such as HNF4 $\alpha$, PKHD1 and UMOD (Tanaka et al, 2004; Rebouissou et al, 2005). We showed expression of $H N F 4 \alpha$ to be well correlated with that of TCF2 and to be upregulated by inducing TCF2 expression using a methyltransferase inhibitor, which suggests alterations in the hepatocyte nuclear factor network can be reversed by inducing TCF2 through demethylation of the gene. Consistent with that idea, Lazarevich et al (2004) reported that expression of $H N F 4 \alpha$ is downregulated in hepatocellular carcinoma and its restoration suppresses tumour growth. It has also been reported that HNF $4 \alpha$ is downregulated in other types of tumours (Lemm et al, 1999) and that it induces expression of 
endothelial Fas ligand (FasL), which prevents cancer cell transmigration (Osanai et al, 2002). Collectively then, the summarised findings suggest that impairment of the HNF1 $\beta$ / HNF $4 \alpha$ signalling network may lead to tumour formation. Similar epigenetic inactivation of a critical regulator of a transcriptional network has been reported for several other genes, including estrogen receptor (Leu et al, 2004) and GATA (Akiyama et al, 2003). Epigenetic inactivation of such transcription factors may affect multiple downstream genes, causing aberrant alteration of signalling pathways involved in a wide array of cellular functions, including growth, differentiation and apoptosis. Conversely, restoration of such transcription factors may lead to upregulation of genes throughout the entire signalling network and restoration of proper function. That said, further study will be necessary to definitively determine the role of epigenetic inactivation of TCF2 in the molecular mechanism of tumorigenesis and progression of ovarian cancer and its utility as a therapeutic target.

\section{ACKNOWLEDGEMENTS}

The authors thank Dr William F Goldman for editing the manuscript. This study was supported in part by Grants-in-Aid for Scientific Research on Priority Areas from the Ministry of Education, Culture, Sports, Science, and Technology (MT, KI and TT).

Supplementary Information accompanies the paper on British Journal of Cancer website (http://www.nature.com/bjc)

\section{REFERENCES}

Akiyama Y, Watkins N, Suzuki H, Jair KW, van Engeland M, Esteller M, Sakai H, Ren CY, Yuasa Y, Herman JG, Baylin SB (2003) GATA-4 and GATA-5 transcription factor genes and potential downstream antitumor target genes are epigenetically silenced in colorectal and gastric cancer. Mol Cell Biol 23: 8429-8439

Balch C, Huang TH, Brown R, Nephew KP (2004) The epigenetics of ovarian cancer drug resistance and resensitization. Am J Obstet Gynecol 191: $1552-1572$

Bellanne-Chantelot C, Chauveau D, Gautier JF, Dubois-Laforgue D, Clauin S, Beaufils S, Wilhelm JM, Boitard C, Noel LH, Velho G, Timsit J (2004) Clinical spectrum associated with hepatocyte nuclear factor-1beta mutations. Ann Intern Med 140: 510-517

Bluteau O, Jeannot E, Bioulac-Sage P, Marques JM, Blanc JF, Bui H, Beaudoin JC, Franco D, Balabaud C, Laurent-Puig P, Zucman-Rossi J (2002) Biallelic inactivation of TCF1 in hepatic adenomas. Nat Genet 32: 312-315

Cereghini S, Raymondjean M, Carranca AG, Herbomel P, Yaniv M (1987) Factors involved in control of tissue-specific expression of albumin gene. Cell 50: 627-638

Chan MW, Wei SH, Wen P, Wang Z, Matei DE, Liu JC, Liyanarachchi S, Brown R, Nephew KP, Yan PS, Huang TH (2005) Hypermethylation of $18 \mathrm{~S}$ and $28 \mathrm{~S}$ ribosomal DNAs predicts progression-free survival in patients with ovarian cancer. Clin Cancer Res 11: 7376-7383

Clark SJ, Harrison J, Paul CL, Frommer M (1994) High sensitivity mapping of methylated cytosines. Nucleic Acids Res 22: 2990-2997

Costello JF (2005) Comparative epigenomics of leukemia. Nat Genet 37: $211-212$

Courtois G, Morgan JG, Campbell LA, Fourel G, Crabtree GR (1987) Interaction of a liver-specific nuclear factor with the fibrinogen and alpha 1-antitrypsin promoters. Science 238: 688-692

Frain M, Swart G, Monaci P, Nicosia A, Stampfli S, Frank R, Cortese R (1989) The liver-specific transcription factor LF-B1 contains a highly diverged homeobox DNA binding domain. Cell 59: 145-157

Haumaitre C, Barbacci E, Jenny M, Ott MO, Gradwohl G, Cereghini S (2005) Lack of TCF2/vHNF1 in mice leads to pancreas agenesis. Proc Natl Acad Sci USA 102: 1490 - 1495

Horikawa Y, Iwasaki N, Hara M, Furuta H, Hinokio Y, Cockburn BN, Lindner T, Yamagata K, Ogata M, Tomonaga O, Kuroki H, Kasahara T, Iwamoto Y, Bell GI (1997) Mutation in hepatocyte nuclear factor-1 beta gene (TCF2) associated with MODY. Nat Genet 17: 384-385

Ishioka S, Sagae S, Terasawa K, Sugimura M, Nishioka Y, Tsukada K, Kudo $R$ (2003) Comparison of the usefulness between a new universal grading system for epithelial ovarian cancer and the FIGO grading system. Gynecol Oncol 89: 447-452

Ishiwata I, Ishiguro T, Ishiwata C, Soma M, Ishikawa H (1986) Establishment and characterization of a human ovarian endodermal sinus tumor cell line - producing specific type of alpha-fetoprotein subfraction. Gynecol Oncol 25: 281-293

Issa JP (2004) CpG island methylator phenotype in cancer. Nat Rev Cancer 4: $988-993$

Jones PA, Baylin SB (2002) The fundamental role of epigenetic events in cancer. Nat Rev Genet 3: 415-428

Kaneuchi M, Sasaki M, Tanaka Y, Shiina H, Verma M, Ebina Y, Nomura E, Yamamoto R, Sakuragi N, Dahiya R (2004) Expression and methylation

status of 14-3-3 sigma gene can characterize the different histological features of ovarian cancer. Biochem Biophys Res Commun 316: $1156-1162$

Kaneuchi M, Sasaki M, Tanaka Y, Shiina H, Yamada H, Yamamoto R, Sakuragi N, Enokida H, Verma M, Dahiya R (2005) WT1 and WT1-AS genes are inactivated by promoter methylation in ovarian clear cell adenocarcinoma. Cancer 104: 1924-1930

Kikuchi Y, Miyauchi M, Kizawa I, Oomori K, Kato K (1986) Establishment of a cisplatin-resistant human ovarian cancer cell line. J Natl Cancer Inst 77: $1181-1185$

Kondo Y, Shen L, Yan PS, Huang TH, Issa JP (2004) Chromatin immunoprecipitation microarrays for identification of genes silenced by histone H3 lysine 9 methylation. Proc Natl Acad Sci USA 101: $7398-7403$

Laird PW (2003) The power and the promise of DNA methylation markers. Nat Rev Cancer 3: 253-266

Laurent-Puig P, Plomteux O, Bluteau O, Zinzindohoue F, Jeannot E, Dahan K, Kartheuser A, Chapusot C, Cugnenc PH, Zucman-Rossi J (2003) Frequent mutations of hepatocyte nuclear factor 1 in colorectal cancer with microsatellite instability. Gastroenterology 124: 1311-1314

Lazarevich NL, Cheremnova OA, Varga EV, Ovchinnikov DA, Kudrjavtseva EI, Morozova OV, Fleishman DI, Engelhardt NV, Duncan SA (2004) Progression of HCC in mice is associated with a downregulation in the expression of hepatocyte nuclear factors. Hepatology 39: 1038-1047

Lemm I, Lingott A, Pogge v Strandmann E, Zoidl C, Bulman MP, Hattersley AT, Schulz WA, Ebert T, Ryffel GU (1999) Loss of HNF1alpha function in human renal cell carcinoma: frequent mutations in the VHL gene but not the HNFlalpha gene. Mol Carcinogen 24: 305-314

Leu YW, Yan PS, Fan M, Jin VX, Liu JC, Curran EM, Welshons WV, Wei SH, Davuluri RV, Plass C, Nephew KP, Huang TH (2004) Loss of estrogen receptor signaling triggers epigenetic silencing of downstream targets in breast cancer. Cancer Res 64: 8184-8192

Obata T, Toyota M, Satoh A, Sasaki Y, Ogi K, Akino K, Suzuki H, Murai M, Kikuchi T, Mita H, Itoh F, Issa JP, Tokino T, Imai K (2003) Identification of HRK as a target of epigenetic inactivation in colorectal and gastric cancer. Clin Cancer Res 9: 6410-6418

Osanai M, Chiba H, Kojima T, Fujibe M, Kuwahara K, Kimura H, Satoh M, Sawada N (2002) Hepatocyte nuclear factor (HNF)-4alpha induces expression of endothelial Fas ligand (FasL) to prevent cancer cell transmigration: a novel defense mechanism of endothelium against cancer metastasis. Jpn J Cancer Res 93: 532-541

Palmisano WA, Crume KP, Grimes MJ, Winters SA, Toyota M, Esteller M, Joste N, Baylin SB, Belinsky SA (2003) Aberrant promoter methylation of the transcription factor genes PAX5 alpha and beta in human cancers. Cancer Res 63: 4620-4625

Rebouissou S, Rosty C, Lecuru F, Boisselier S, Bui H, Le Frere-Belfa MA, Sastre X, Laurent-Puig P, Zucman-Rossi J (2004) Mutation of TCF1 encoding hepatocyte nuclear factor lalpha in gynecological cancer. Oncogene 23: $7588-7592$

Rebouissou S, Vasiliu V, Thomas C, Bellanne-Chantelot C, Bui H, Chretien Y, Timsit J, Rosty C, Laurent-Puig P, Chauveau D, Zucman-Rossi J (2005) Germline hepatocyte nuclear factor lalpha and lbeta mutations in renal cell carcinomas. Hum Mol Genet 14: 603-614 
Rey-Campos J, Chouard T, Yaniv M, Cereghini S (1991) vHNF1 is a homeoprotein that activates transcription and forms heterodimers with HNF1. EMBO J 10: 1445 - 1457

Sugiyama T, Kamura T, Kigawa J, Terakawa N, Kikuchi Y, Kita T, Suzuki M, Sato I, Taguchi K (2000) Clinical characteristics of clear cell carcinoma of the ovary: a distinct histologic type with poor prognosis and resistance to platinum-based chemotherapy. Cancer 88: $2584-2589$

Suzuki H, Gabrielson E, Chen W, Anbazhagan R, van Engeland M, Weijenberg MP, Herman JG, Baylin SB (2002) A genomic screen for genes upregulated by demethylation and histone deacetylase inhibition in human colorectal cancer. Nat Genet 31: 141-149

Takada T, Yagi Y, Maekita T, Imura M, Nakagawa S, Tsao SW, Miyamoto K, Yoshino O, Yasugi T, Taketani Y, Ushijima T (2004) Methylationassociated silencing of the Wnt antagonist SFRP1 gene in human ovarian cancers. Cancer Sci 95: 741-744

Tanaka T, Tomaru Y, Nomura Y, Miura H, Suzuki M, Hayashizaki Y (2004) Comprehensive search for HNF-1beta-regulated genes in mouse hepatoma cells perturbed by transcription regulatory factor-targeted RNAi. Nucleic Acids Res 32: 2740-2750

Teodoridis JM, Hall J, Marsh S, Kannall HD, Smyth C, Curto J, Siddiqui N, Gabra H, McLeod HL, Strathdee G, Brown R (2005) CpG island methylation of DNA damage response genes in advanced ovarian cancer. Cancer Res 65: 8961-8967

Terasawa K, Sagae S, Toyota M, Tsukada K, Ogi K, Satoh A, Mita H, Imai K, Tokino T, Kudo R (2004) Epigenetic inactivation of TMS1/ASC in ovarian cancer. Clin Cancer Res 10: 2000-2006

Toyota M, Ho C, Ahuja N, Jair KW, Li Q, Ohe-Toyota M, Baylin SB, Issa JP (1999) Identification of differentially methylated sequences in colorectal cancer by methylated CpG island amplification. Cancer Res 59: $2307-2312$
Ueda M, Ueki M, Yamada T, Okamoto Y, Maeda T, Sugimoto O, Otsuki Y (1989) Scatchard analysis of EGF receptor and effects of EGF on growth and TA-4 production of newly established uterine cervical cancer cell line (OMC-1). Hum Cell 2: 401-410

Ueki T, Toyota M, Skinner H, Walter KM, Yeo CJ, Issa JP, Hruban RH, Goggins M (2001) Identification and characterization of differentially methylated $\mathrm{CpG}$ islands in pancreatic carcinoma. Cancer Res 61: $8540-8546$

Ueno M, Toyota M, Akino K, Suzuki H, Kusano M, Satoh A, Mita H, Sasaki Y, Nojima M, Yanagihara K, Hinoda Y, Tokino T, Imai K (2004) Aberrant methylation and histone deacetylation associated with silencing of SLC5A8 in gastric cancer. Tumour Biol 25: 134-140

Xiong Z, Laird PW (1997) COBRA: a sensitive and quantitative DNA methylation assay. Nucleic Acids Res 25: 2532-2534

Yamada Y, Toyota M, Hirokawa Y, Suzuki H, Takagi A, Matsuzaki T, Sugimura Y, Yatani R, Shiraishi T, Watanabe M (2004) Identification of differentially methylated $\mathrm{CpG}$ islands in prostate cancer. Int J Cancer 112: $840-845$

Yu L, Liu C, Vandeusen J, Becknell B, Dai Z, Wu YZ, Raval A, Liu TH, Ding W, Mao C, Liu S, Smith LT, Lee S, Rassenti L, Marcucci G, Byrd J, Caligiuri MA, Plass C (2005) Global assessment of promoter methylation in a mouse model of cancer identifies ID4 as a putative tumor-suppressor gene in human leukemia. Nat Genet 37: 265-274

Yu Y, Xu F, Peng H, Fang X, Zhao S, Li Y, Cuevas B, Kuo WL, Gray JW, Siciliano M, Mills GB, Bast Jr RC (1999) NOEY2 (ARHI), an imprinted putative tumor suppressor gene in ovarian and breast carcinomas. Proc Natl Acad Sci USA 96: 214-219

Zardo G, Tiirikainen MI, Hong C, Misra A, Feuerstein BG, Volik S, Collins CC, Lamborn KR, Bollen A, Pinkel D, Albertson DG, Costello JF (2002) Integrated genomic and epigenomic analyses pinpoint biallelic gene inactivation in tumors. Nat Genet 32: $453-458$ 